\title{
Histone H3K27 Modifications and Gene Transcription
}

AeRi Kim*

Department of Molecular Biology, College of Natural Sciences, Pusan National University, Pusan 609-735, Korea

Received January 26, 2011 /Accepted February 23, 2011

\begin{abstract}
Lysine residues of histone $\mathrm{H} 3$ and $\mathrm{H} 4$ are covalently modified in the chromatin of eukaryotic cells. Lysine 27 in histone $\mathrm{H} 3$ was acetylated (H3K27ac) or methylated at three levels; mono-, di-, and trimethylation (H3K27me1, H3K27me2, and H3K27me3). These modifications at H3K27 were related with gene transcription and/or chromatin structure in distinct patterns. Generally, H3K27ac and H3K27me1 were enriched in active chromatin, such as the locus control region or transcriptionally active genes, while transcriptionally inactive genes were highly marked by H3K27me2 and H3K27me3. These modifications appear to have been catalyzed by distinct histone-modifying enzymes. Recent studies suggest that the four kinds of modifications at $\mathrm{H} 3 \mathrm{~K} 27$ have inter-correlation in gene transcription or chromatin structure formation.
\end{abstract}

Key words : Histone H3K27, acetylation, methylation, transcription

\section{서 론}

히스톤(histone)은 크로마틴(chromatin)의 구조 단백질로 서 DNA와 결합하여 뉴클레오좀(nucleosome)을 형성한다. 뉴 클레오좀의 핵심 부분(core region)에는 네 종류의 히스톤 $(\mathrm{H} 2 \mathrm{~A}, \mathrm{H} 2 \mathrm{~B}, \mathrm{H} 3, \mathrm{H} 4)$ 으로 구성된 팔량체(octamer)가 존재하 며, 이들은 약 $146 \mathrm{bp}$ 의 DNA와 결합하고 있다. 크로마틴 환경 에서 이들 핵심 히스톤의 $\mathrm{N}$ 말단 부위 아미노산들은 공유 변 형(covalent modification)에 의해 변화될 수 있으며, 지금까지 다양한 종류의 공유변형이 밝혀졌다. 그 대표적 예로 아세틸 화(acetylation)와 메틸화(methylation)가 있으며, 이 변형들은 각각 히스톤과 $\mathrm{DNA}$ 사이의 결합 정도를 변화시키거나 크로 마틴 결합 단백질을 위한 인식 지점을 제공함으로써 크로마틴 구조 형성과 유전자 전사 조절에 관여한다[12]. 히스톤 $\mathrm{H} 3$ 의 경우, $\mathrm{N}$ 말단 부위에 여러 개의 라이신(K)이 존재하며, 이들 $\mathrm{K} 4, \mathrm{~K} 9, \mathrm{~K} 14, \mathrm{~K} 27$ 에서 아세틸화 또는 메틸화가 일어나는 것이 확인되었다(Fig. 1).

히스톤 H3의 27번째 라이신, H3K27은 크로마틴 환경에서 아세틸화되거나 메틸화된다[18]. H3K27의 메틸화는 polycomb group ( $\mathrm{PcG}$ ) 단백질에 존재하는 메틸화효소 EZH2에 의해 촉매되며, PcG 단백질은 다세포 동물의 초기 발생 과정 에서 호메오 유전자(homeotic gene)의 전사를 억제하는데 기 여한다[19,21]. 이는 PcG에 의한 H3K27 메틸화가 유전자 전사 를 조절하는 중요 기작임을 의미하며, 지금까지의 연구들은 유전자의 전사 억제 과정에서 $\mathrm{H} 3 \mathrm{~K} 27$ 메틸화가 동반됨을 보여 주었다. 특히 세 개의 메틸기가 첨가되는 $\mathrm{H} 3 \mathrm{~K} 27 \mathrm{me}$ 는 배아시

*Corresponding author Tel : +82-51-510-3683, Fax : +82-51-513-9258

E-mail : kimaeri@pusan.ac.kr

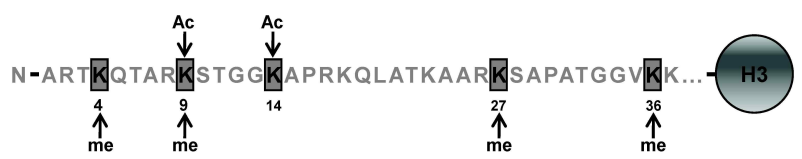

Fig. 1. Covalent modifications at histone H3. Amino acids of histone $\mathrm{H} 3 \mathrm{~N}$ terminal are represented in diagram. Acetylation and methylation at lysine residues are marked.

기의 발생 과정, 암 세포의 변형 과정, 그리고 줄기세포의 분화 능 등에 관여하는 것으로 밝혀졌다[3,22]. 또한 최근 들어 H3K27의 여러 변형들 사이의 관계 및 이들 변형과 유전자 전사 사이의 관련성이 보고되면서 메틸화 뿐 만 아니라 아세 틸화에 대한 연구가 활발히 진행되고 있다.

이 총설에서는 히스톤 $\mathrm{H} 3 \mathrm{~K} 27$ 에서 일어나는 네 가지의 공 유 변형에 대해 살펴보고자 한다. 포유류 세포를 중심으로 $\mathrm{H} 3 \mathrm{~K} 27$ 의 각 변형과 유전자 전사 사이의 상관 관계에 대한 연구들을 정리해보고, 각 변형을 담당하는 효소들에 대해서도 살펴보고자 한다. 또한 생쥐 글로빈 좌위에서 수행된 연구를 바탕으로 유전자 전사 활성화 과정에서 이들 히스톤 변형이 어떤 순서로 첨가되거나 제거되는지 설명하고자 한다.

\section{히스톤 H3K27 메틸화}

히스톤 $\mathrm{H} 3 \mathrm{~K} 27$ 의 메틸화는 PcG 단백질들의 복합체인 Polycomb repressive complex 2 (PRC2)에 의해 일어난다. 사 람의 경우, $\mathrm{PRC2}$ 는 네 개의 핵심 단위체(core subunit), EZH2, $\mathrm{EED}, \mathrm{SUZ12}, \mathrm{RBAP} 48$ 를 가지고 있으며, 이들 중 $\mathrm{EZH2}$ 는 메틸 화를 촉매하는 효소 활성을 가지고 있다[2,14]. 실제로 세포 내에서 $\mathrm{EZH} 2$ 를 제거하면 $\mathrm{H} 3 \mathrm{~K} 27 \mathrm{me} 2 / \mathrm{me} 3$ 단백질의 양이 현 

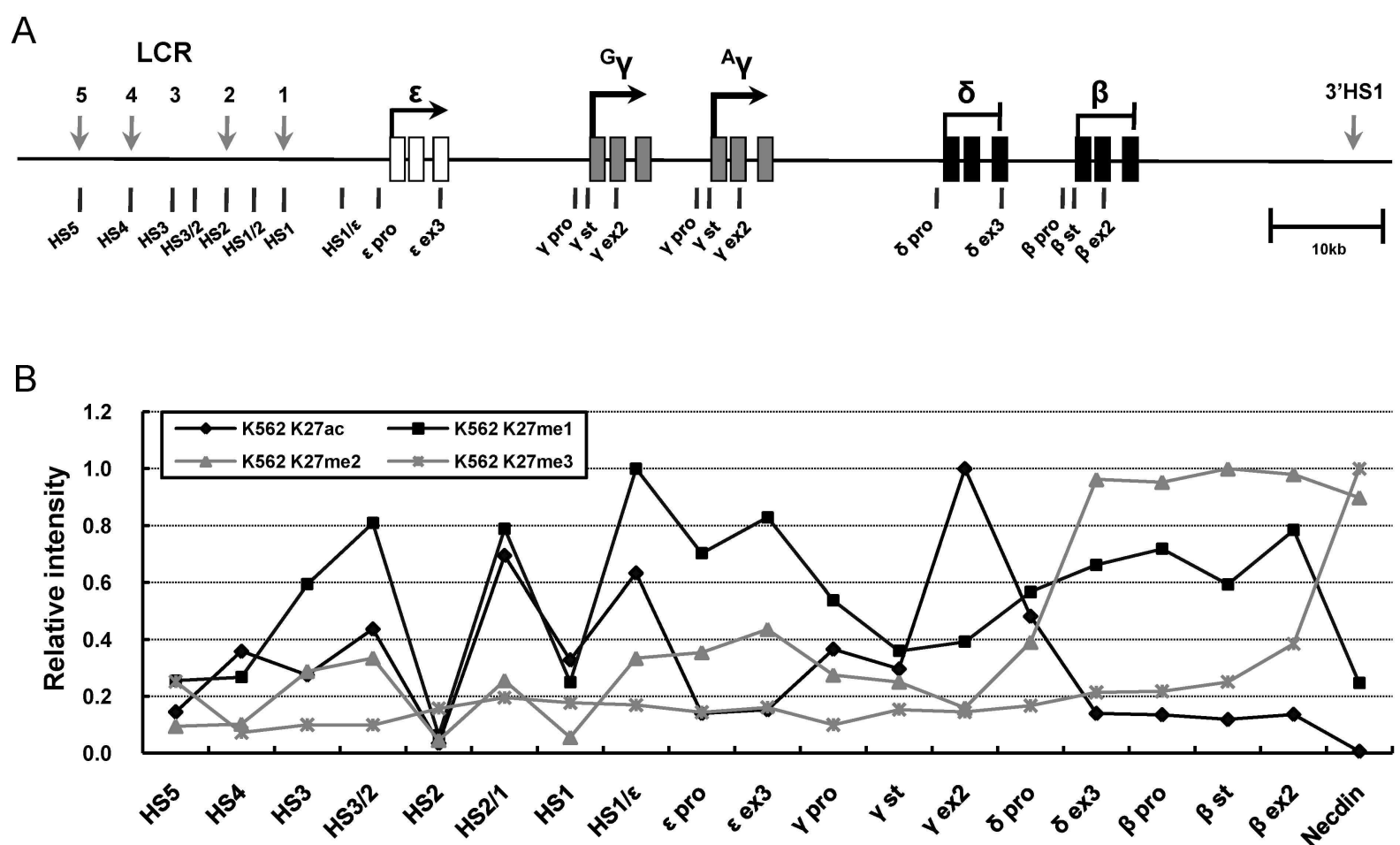

Fig. 2. Histone modifications at histone H3K27 in the human $\beta$-globin locus. (A) The five globin genes and hypersensitive sites of locus control region are represented in diagram. Transcription level of the globin genes in human erythroid K562 cells was represented by arrow at the gene. The locations of amplicons for real-time PCR are indicated with vertical bars below the diagram. (B) Acetylation and methylation (mono-, di- and trimethylation) pattern of histone H3K27 was represented through the globin locus. The levels of histone modifications were measured by chromatin immunoprecipitation and real-time PCR, and then plotted in a graph by setting the highest value for each antibody equal to 1 . Adapted from [11].

저히 감소하며[20], 이와 반대로 $\mathrm{EZH2}$ 를 과발현시키면 표적 유전자의 $\mathrm{H} 3 \mathrm{~K} 27 \mathrm{me} 2 / \mathrm{me} 3$ 수준이 증가한다[5]. 또한 PRC2의 구성 성분인 EED나 SUZ12도 메틸화 촉매 기능 자체를 가지고 있지는 않지만, H3K27의 메틸화를 위해 필요하다. 배아줄기 세포나 생쥐 배아에서 이들 단백질을 제거할 경우, $\mathrm{EZH} 2$ 의 감소와 함께 $\mathrm{H} 3 \mathrm{~K} 27 \mathrm{me} 2 / \mathrm{me} 3$ 단백질의 양이 감소하는 것을 볼 수 있다[15,16]. H3K27의 또 다른 메틸화 촉매 단위체로 $\mathrm{EZH} 2$ 와 유사한 EZH1이 보고되었다. 이 단백질은 배아줄기세 포의 분화능과 관련된 $\mathrm{EZH2}$ 의 역할을 부분적으로 대체할 수 있는 것으로 보이며, 이는 EZH1이 H3K27me3에 관여하기 때 문일 것이다[20].

메틸기가 하나 결합되어 있는 $\mathrm{H} 3 \mathrm{~K} 27 \mathrm{me}$ 은 전사가 활발한 유전자나 LCR (locus control region) 등에서 관찰된다. 메틸기 가 두 개 또는 세 개 결합된 $\mathrm{H} 3 \mathrm{~K} 27 \mathrm{me} 2$ 나 H3K27me3에 비해 연구된 바가 많지 않지만, 지금까지의 보고들은 H3K27me1이 히스톤의 활성 표지(active mark)임을 보여준다. 사람의 게놈 전체를 대상으로 한 연구에서 $\mathrm{H} 3 \mathrm{~K} 27 \mathrm{me} 1$ 은 전사 수준이 아주 높거나 또는 비교적 높은 유전자에서 많이 관찰되며[1], 사람 글로빈 좌위를 대상으로 한 연구는 전사가 활발한 유전자 뿐 만 아니라, 전사조절부위인 LCR도 높은 수준의 H3K27me1가
일어나는 곳임을 보여준다[11](Fig. 2). 그러나 적혈구 계통이 아닌 세포에서는 아주 낮은 수준의 $\mathrm{H} 3 \mathrm{~K} 27 \mathrm{me} 1$ 이 글로빈 좌위 의 $\mathrm{LCR}$ 에 해당되는 부분에서 관찰되며, 이는 적어도 $\mathrm{H} 3 \mathrm{~K} 27 \mathrm{me1}$ 이 불활성 히스톤 표지가 아님을 의미한다.

$\mathrm{EZH} 2$ 가 H3K27me1를 촉매하는지는 확실하지 않다. 이는 $\mathrm{EZH2}$ 메틸화 효소를 포함한 $\mathrm{PRC} 2$ 의 단위체들을 제거하였을 때, H3K27me1 단백질의 양이 항상 감소하는 것은 아니기 때 문이다. 배아줄기세포에서 EED 단위체를 제거하면 EZH2도 감소하며, 그 결과 모든 종류의 $\mathrm{H} 3 \mathrm{~K} 27$ 메틸화가 감소한다[15]. 그러나 생쥐 배아에서 SUZ12 단위체를 제거하면 $\mathrm{EZH2}$ 의 감 소와 함께 $\mathrm{H} 3 \mathrm{~K} 27 \mathrm{me} 2 / \mathrm{me} 3$ 단백질 양은 줄어들지만 H3K27me1 단백질 양은 유지된다[16]. 또한 EZH2가 제거된 배아줄기세포의 경우, $\mathrm{H} 3 \mathrm{~K} 27 \mathrm{me} 2 / \mathrm{me} 3$ 은 감소하지만, $\mathrm{EED}$, SUZ12와 더불어 H3K27me1 수준은 큰 변화 없이 유지된다 [20]. 이러한 연구들은 $\mathrm{H} 3 \mathrm{~K} 27 \mathrm{me} 2 / \mathrm{me} 3$ 와 달리 H3K27me1가 $\mathrm{PRC} 2$ 또는 $\mathrm{EZH} 2$ 에 의해 직접적으로 영향을 받는 것은 아님 을 보여주며, 사람 글로빈 좌위의 EZH2와 SUZ12 분포도 $\mathrm{H} 3 \mathrm{~K} 27 \mathrm{me} 1$ 가 이들 $\mathrm{PRC} 2$ 와 직접적인 관련은 없는 것으로 보 인다[11].

H3K27me2은 전사가 일어나지 않은 유전자에서 흔히 발견 
된다. 인간 게놈을 대상으로 $\mathrm{ChIP}$ (chromatin immunoprecipitation)과 차세대 염기서열분석 기법(ChIP-Seq) 을 이용하여 수행한 연구는 $\mathrm{H} 3 \mathrm{~K} 27 \mathrm{me} 2$ 가 유전자 전사 정도에 반비례하게 일어남을 보여준다[1]. 또한 적혈구 세포주 K562 에서 사람 글로빈 좌위를 모델로 ChIP과 real time-PCR 기법 을 이용한 연구도 같은 패턴의 상관관계를 보여준다[11](Fig. 2). 즉, 전사가 억제된 $\delta$-와 $\beta$-글로빈 유전자는 매우 높은 수준 으로 $\mathrm{H} 3 \mathrm{~K} 27 \mathrm{me} 2$ 가 일어나지만, 전사가 활발한 $\mathrm{\gamma}$-글로빈 유전 자는 낮은 수준의 $\mathrm{H} 3 \mathrm{~K} 27 \mathrm{me} 2$ 를 보여주며, 중간 정도의 전사 수준을 나타내는 $\varepsilon$-글로빈 유전자는 $\mathrm{H} 3 \mathrm{~K} 27 \mathrm{me} 2$ 도 중간 수준 이다. 그러나 유전자의 전사 수준이 $\mathrm{H} 3 \mathrm{~K} 27 \mathrm{me} 2$ 정도를 결정하 는 유일한 요인은 아닌 것으로 보인다. 그 이유는 비적혈구 세포의 글로빈 유전자들은 전사가 전혀 일어나지 않지만, $\mathrm{H} 3 \mathrm{~K} 27 \mathrm{me} 2$ 수준은 매우 낮으며, 그 대신 높은 수준의 $\mathrm{H} 3 \mathrm{~K} 27 \mathrm{me} 3$ 이 관찰된다.

$\mathrm{H} 3 \mathrm{~K} 27 \mathrm{me} 3$ 도 $\mathrm{H} 3 \mathrm{~K} 27 \mathrm{me} 2$ 처럼 전사가 억제된 유전자의 히 스톤 표지다. 전사가 활발히 일어나는 유전자에서는 $\mathrm{H} 3 \mathrm{~K} 27 \mathrm{me}$ 는 관찰되지 않으며[25] 발생 과정 등에서 일어나 는 유전자 전사 억제는 $\mathrm{H} 3 \mathrm{~K} 27 \mathrm{me} 3$ 를 동반한다[13]. 또한 $\mathrm{H} 3 \mathrm{~K} 27$ 메틸화 효소의 인위적 감소에 따른 $\mathrm{H} 3 \mathrm{~K} 27 \mathrm{me} 3$ 감소는 표적 유전자의 전사를 증가시킨다[6]. ChIP-Seq 기법을 이용 한 대량 분석 결과도 같은 맥락의 패턴을 보여 준다. 사람 면역 세포에서 약 12,000 개의 유전자를 ChIP-Seq 기법으로 분석한 결과, $\mathrm{H} 3 \mathrm{~K} 27 \mathrm{me} 3$ 과 유전자 전사 수준 사이에 반비례 관계가 존재한다[1]. 사람 글로빈 유전자의 경우, 비적혈구 세포주에 서 글로빈 좌위 전체가 높은 수준의 $\mathrm{H} 3 \mathrm{~K} 27 \mathrm{me} 3$ 를 보이지만, 적혈구 세포주의 불활성 글로빈 유전자들은 낮은 수준으로 H3K27me3가 되어있다[11](Fig. 2). 이러한 현상은 적혈구 세 포주에서 글로빈 좌위 전체의 조직특이적 활성화와 관련이 있는 것으로 보이며, 생쥐 글로빈 좌위에서도 비슷한 현상이 관찰된다. 이처럼 다양한 세포의 여러 유전자에서 나타난 결 과들은 $\mathrm{H} 3 \mathrm{~K} 27 \mathrm{me} 3$ 이 전사 억제와 관련 있음을 보여주며, 전사 억제 및 불활성 크로마틴 구조 형성을 위해 H3K27me3이 $\mathrm{H} 3 \mathrm{~K} 27 \mathrm{me} 2$ 보다 한 단계 높은 역할을 하는 것으로 생각된다.

사람과 생쥐의 글로빈 좌위에서 나타난 $\mathrm{H} 3 \mathrm{~K} 27 \mathrm{me} 2$ 과 $\mathrm{H} 3 \mathrm{~K} 27 \mathrm{me} 3$ 의 서로 다른 분포 패턴은 두 변형이 모두 PRC2 복합체 또는 $\mathrm{EZH} 2$ 메틸화효소에 의해 일어나는지 의문을 제 기한다. 사람 글로빈 좌위의 경우, $\mathrm{PRC} 2$ 의 소단위인 SUZ12와 $\mathrm{EZH} 2$ 는 적혈구 세포에 비해 비적혈구 세포에서 더 많이 결합 하고 있으며, 특히 비적혈구 세포에서 이들 소단위의 결합 분 포는 $\mathrm{H} 3 \mathrm{~K} 27 \mathrm{me} 3$ 분포와 대략적으로 일치한다[11]. 이는 PRC2 가 $\mathrm{H} 3 \mathrm{~K} 27 \mathrm{me} 2$ 보다 $\mathrm{H} 3 \mathrm{~K} 27 \mathrm{me} 3$ 와 관련되어 있음을 의미한다. 또한 몇몇 연구들은 H3K9 메틸화효소인 G9a가 H3K27me2에 기여함을 보여준다. G9a는 in vitro 상황에서 $\mathrm{H} 3 \mathrm{~K} 27$ 에 메틸기 를 첨가할 수 있으며[23], G9a가 제거된 생쥐 배아줄기세포에 서 여러 좌위의 $\mathrm{H} 3 \mathrm{~K} 9 \mathrm{me} 2$ 수준뿐 만 아니라, H3K27me2 수준
도 현저히 감소한다[7]. 더욱이 최근 연구는 $\mathrm{G9a}$ 의 감소에 의 해 세포 내 $\mathrm{H} 3 \mathrm{~K} 9 \mathrm{me} 2$ 단백질 양과 함께 $\mathrm{H} 3 \mathrm{~K} 27 \mathrm{me} 2$ 단백질 양도 감소함을 보여주며, 특히 이때 $\mathrm{EZH} 2$ 양과 $\mathrm{H} 3 \mathrm{~K} 27 \mathrm{me} 3$ 양은 큰 변화없이 유지된다[4]. 이러한 연구들은 $\mathrm{H} 3 \mathrm{~K} 27 \mathrm{me} 2$ 과 $\mathrm{H} 3 \mathrm{~K} 27 \mathrm{me} 3$ 이 서로 다른 효소에 의해 촉매되며, 크로마틴 환경 에서 그 역할이 다를 수 있음을 시사한다.

\section{히스톤 H3K27 아세틸화}

히스톤 $\mathrm{H} 3 \mathrm{~K} 27$ 의 아세틸화는 다른 라이신 잔기의 아세틸 화와 마찬가지로 전사가 활발한 유전자에서 일어난다. 사람 글로빈 좌위의 유전자들에서 $\mathrm{H} 3 \mathrm{~K} 27 \mathrm{ac}$ 정도는 전사 정도에 비례하며, LCR에서도 높은 수준의 $\mathrm{H} 3 \mathrm{~K} 27 \mathrm{ac}$ 이 관찰된다 [11](Fig. 2). 또한 전체적인 글로빈 좌위의 $\mathrm{H} 3 \mathrm{~K} 27 \mathrm{ac}$ 분포 패 턴은 대표적 아세틸화 잔기인 히스톤 $\mathrm{H} 3 \mathrm{~K} 9 / \mathrm{K} 14$ 의 아세틸 화 패턴과 비슷하다[8]. 그리고 특이하게도 글로빈 좌위의 $\mathrm{H} 3 \mathrm{~K} 27 \mathrm{ac}$ 분포 패턴은 $\mathrm{H} 3 \mathrm{~K} 27 \mathrm{me}$ 과 대칭된다. 아울러 전사 가 많이 일어나는 유전자들을 대량으로 조사한 연구는 프로 모터 주위에서 아세틸화가 많이 일어남을 보여준다[26]. 이 러한 연구들은 $\mathrm{H} 3 \mathrm{~K} 27 \mathrm{ac}$ 이 또 하나의 활성 상태 크로마틴에 대한 히스톤 변형 표지임을 의미한다. 배아줄기세포도 비슷 한 패턴이 관찰되는데, 분화 과정에서 전사가 활성화 되는 유전자들은 $\mathrm{H} 3 \mathrm{~K} 27 \mathrm{ac}$ 수준이 증가하며, 반대로 전사가 억제 되는 유전자들은 $\mathrm{H} 3 \mathrm{~K} 27 \mathrm{ac}$ 수준이 감소된다. 또한 배아줄기 세포에서 $\mathrm{H} 3 \mathrm{~K} 27 \mathrm{ac}$ 단백질 양은 $\mathrm{PRC} 2$ 의 SUZ12 또는 EED 제 거에 의한 $\mathrm{H} 3 \mathrm{~K} 27 \mathrm{me} 3$ 양의 감소에 따라 증가하며, $\mathrm{EZH} 2$ 의 과발현은 표적 유전자의 전사 및 이들 유전자의 $\mathrm{H} 3 \mathrm{~K} 27 \mathrm{ac}$ 수 준을 감소시킨다[17]. 초파리 세포에서 $\mathrm{E}(\mathrm{Z})$ 를 제거하는 경우 도 $\mathrm{H} 3 \mathrm{~K} 27 \mathrm{me} 3$ 양의 감소와 함께 $\mathrm{H} 3 \mathrm{~K} 27 \mathrm{ac}$ 양의 증가를 가져 온다[24].

$\mathrm{H} 3 \mathrm{~K} 27 \mathrm{ac}$ 은 $\mathrm{CBP}$ 아세틸화효소에 의해 촉매되는 것으로 보 인다. 초파리 세포나 생쥐 배아줄기세포에서 $\mathrm{CBP}$ 를 제거하면 $\mathrm{H} 3 \mathrm{~K} 27 \mathrm{ac}$ 단백질의 양은 크게 감소하며, 반대로 $\mathrm{CBP}$ 가 과발현 된 초파리는 상대적으로 많은 양의 $\mathrm{H} 3 \mathrm{~K} 27 \mathrm{ac}$ 단백질을 가지고 있다[17,24]. 이러한 결과들은 대표적 라이신 아세틸화 효소인 $\mathrm{CBP}$ 가 $\mathrm{H} 3 \mathrm{~K} 27$ 에도 작용함을 보여준다. 또한 $\mathrm{H} 3 \mathrm{~K} 27 \mathrm{ac}$ 은 유전 자 전사 조절부위인 인핸서(enhancer)에 의해 일어나며, 이는 인핸서에 모집되는 $\mathrm{CBP}$ 의 작용과 관련된 것으로 보인다[9].

\section{유전자 전사 활성 과정에서 히스톤 H3K27 변형}

유전자 전사가 활성화되거나 반대로 억제되는 과정 동안 다양한 종류의 히스톤 변형들이 더해지거나 제거된다. 일반 적으로 전사가 활성화되는 과정 동안 라이신 잔기의 아세틸 화 같은 활성 표지들이 추가되고, 그 대신 $\mathrm{H} 3 \mathrm{~K} 9 \mathrm{me} 2$ 같은 불 활성 표지들은 제거된다. $\mathrm{H} 3 \mathrm{~K} 27$ 의 여러 변형들도 전사 활성 
화 과정에서 추가되거나 제거되며, 각 표지들의 추가와 제거 는 특정 시점에서 이루어지는 것으로 보인다. 생쥐 글로빈 좌위의 $\beta$-major 글로빈 유전자를 모델로 전사 활성 과정 동 안의 H3K27 변화를 시간 별로 분석한 연구는 예상처럼 $\mathrm{H} 3 \mathrm{~K} 27 \mathrm{ac}$ 정도가 전사 활성 유도 후 증가하며, 그 시점은 실 질적인 유전자 전사가 시작되기 이전임을 보여준다[10]. 또 한 H3K27ac는 활성화되는 유전자뿐만 아니라 LCR에서도 같은 시점에 급격히 증가된다. 이에 반해 글로빈 유전자의 H3K27me2 수준은 전사 활성화 이전에 높게 유지되다가 활 성 유도 후 전사가 실질적으로 시작되는 시점에서 급격히 감 소한다. 그리고 이 글로빈 좌위의 경우, $\mathrm{H} 3 \mathrm{~K} 27 \mathrm{me} 3$ 는 전사 활성 유도 이전부터 유전자와 LCR 모두에서 낮은 수준으로 유지되는데, 이것은 조직특이적 유전자 좌위의 기본적 활성 상태와 관련이 있는 것으로 보인다.

\section{히스톤 H3K27 변형 연구 방향}

본 총설에서는 히스톤 $\mathrm{H} 3 \mathrm{~K} 27$ 에서 일어나는 메틸화와 아세 틸화가 유전자 전사와 어떤 관계가 있는지 살펴뵀다. 특히 이 아미노산 잔기에서 일어나는 메틸화는 첨가되는 메틸기의 숫 자에 따라 유전자 전사의 활성 및 억제와 각각 다른 관계를 보여주고 있다. 그러나 각 변화들의 기능적 의미와 변화를 촉 매하는 효소의 종류 및 작용 기작들은 좀 더 명확히 연구되고 설명되어야 할 것이다. 또한 다른 아미노산 잔기에서 일어나 는 변형들과의 관계나 상호 작용, 그리고 뉴클레오좀 리모델 링 및 크로마틴 looping 같은 입체 구조 형성과의 관계 및 역할 등도 설명되어야 할 부분이다.

\section{감사의 글}

이 논문은 부산대학교 자유과제 학술연구비(2년)에 의하여 연구되었음.

\section{References}

1. Barski, A., S. Cuddapah, K. Cui, T. Y. Roh, D. E. Schones, Z. Wang, G. Wei, I. Chepelev, and K. Zhao. 2007. High-resolution profiling of histone methylations in the human genome. Cell 129, 823-837.

2. Cao, R., L. Wang, H. Wang, L. Xia, H. Erdjument-Bromage, P. Tempst, R. S. Jones, and Y. Zhang. 2002. Role of histone H3 lysine 27 methylation in Polycomb-group silencing. Science 298, 1039-1043.

3. Cao, R. and Y. Zhang. 2004. The functions of E(Z)/EZH2-mediated methylation of lysine 27 in histone H3. Curr. Opin. Genet. Dev. 14, 155-164.

4. Chaturvedi, C., A. M. Hosey, C. Palii, C. Perez-Iratxeta, Y. Nakatani, J. A. Ranish, F. J. Dilworth, and M. Brand. 2009.
Dual role for the methyltransferase G9a in the maintenance of beta-globin gene transcription in adult erythroid cells. Proc. Natl. Acad Sci. USA. 106, 18303-18308.

5. Chen, H., S. W. Tu, and J. T. Hsieh. 2005. Down-regulation of human DAB2IP gene expression mediated by polycomb Ezh2 complex and histone deacetylase in prostate cancer. J. Biol. Chem 280, 22437-22444.

6. Fujii, S., K. Ito, Y. Ito, and A. Ochiai. 2008. Enhancer of zeste homologue 2 (EZH2) down-regulates RUNX3 by increasing histone H3 methylation. J. Biol. Chem 283, 17324-17332.

7. Ikegami, K., M. Iwatani, M. Suzuki, M. Tachibana, Y. Shinkai, S. Tanaka, J. M. Greally, S. Yagi, N. Hattori, and K. Shiota. 2007. Genome-wide and locus-specific DNA hypomethylation in G9a deficient mouse embryonic stem cells. Genes Cells 12, 1-11.

8. Kim, A., C. M. Kiefer, and A. Dean. 2007. Distinctive signatures of histone methylation in transcribed coding and noncoding human beta-globin sequences. Mol. Cell Biol. 27, 1271-1279.

9. Kim, A., H. Zhao, I. Ifrim, and A. Dean. 2007. Beta-globin intergenic transcription and histone acetylation dependent on an enhancer. Mol. Cell Biol. 27, 2980-2986.

10. Kim, K. and A. Kim. 2010. Sequential changes in chromatin structure during transcriptional activation in the beta globin LCR and its target gene. Int. J. Biochem Cell Biol. 42, 1517-1524.

11. Kim, Y. W. and A. Kim. 2011. Characterization of histone H3K27 modifications in the $\beta$-globin locus. Biochem Biophys. Res. Commun. 405, 210-215.

12. Kouzarides, T. 2007. Chromatin modifications and their function. Cell 128, 693-705.

13. Koyanagi, M., A. Baguet, J. Martens, R. Margueron, T. Jenuwein, and M. Bix. 2005. EZH2 and histone 3 trimethyl lysine 27 associated with II4 and Il13 gene silencing in Th1 cells. J. Biol. Chem 280, 31470-31477.

14. Kuzmichev, A., K. Nishioka, H. Erdjument-Bromage, P. Tempst, and D. Reinberg. 2002. Histone methyltransferase activity associated with a human multiprotein complex containing the Enhancer of Zeste protein. Genes Dev. 16, 2893-2905.

15. Montgomery, N. D., D. Yee, A. Chen, S. Kalantry, S. J. Chamberlain, A. P. Otte, and T. Magnuson. 2005. The murine polycomb group protein Eed is required for global histone H3 lysine-27 methylation. Curr. Biol. 15, 942-947.

16. Pasini, D., A. P. Bracken, M. R. Jensen, D. E. Lazzerini, and K. Helin. 2004. Suz12 is essential for mouse development and for EZH2 histone methyltransferase activity. EMBO J. 23, 4061-4071.

17. Pasini, D., M. Malatesta, H. R. Jung, J. Walfridsson, A. Willer, L. Olsson, J. Skotte, A. Wutz, B. Porse, O. N. Jensen, and K. Helin. 2010. Characterization of an antagonistic switch between histone $\mathrm{H} 3$ lysine 27 methylation and acetylation in the transcriptional regulation of Polycomb group target genes. Nucleic Acids Res. 38, 4958-4969.

18. Peters, A. H., S. Kubicek, K. Mechtler, R. J. O'Sullivan, A. A. Derijck, L. Perez-Burgos, A. Kohlmaier, S. Opravil, M. 
Tachibana, Y. Shinkai, J. H. Martens, and T. Jenuwein. 2003. Partitioning and plasticity of repressive histone methylation states in mammalian chromatin. Mol. Cell 12, 1577-1589.

19. Schuettengruber, B., D. Chourrout, M. Vervoort, B. Leblanc, and G. Cavalli. 2007. Genome regulation by polycomb and trithorax proteins. Cell 128, 735-745.

20. Shen, X., Y. Liu, Y. J. Hsu, Y. Fujiwara, J. Kim, X. Mao, G. C. Yuan, and S. H. Orkin. 2008. EZH1 mediates methylation on histone $\mathrm{H} 3$ lysine 27 and complements EZH2 in maintaining stem cell identity and executing pluripotency. Mol. Cell 32, 491-502.

21. Simon, J. A. and R. E. Kingston. 2009. Mechanisms of polycomb gene silencing: knowns and unknowns. Nat. Rev. Mol. Cell Biol. 10, 697-708.

22. Simon, J. A. and C. A. Lange. 2008. Roles of the EZH2 histone methyltransferase in cancer epigenetics. Mutat. Res. 647, 21-29.

23. Tachibana, M., K. Sugimoto, T. Fukushima, and Y. Shinkai.
2001. Set domain-containing protein, G9a, is a novel lysine-preferring mammalian histone methyltransferase with hyperactivity and specific selectivity to lysines 9 and 27 of histone H3. J. Biol. Chem 276, 25309-25317.

24. Tie, F., R. Banerjee, C. A. Stratton, J. Prasad-Sinha, V. Stepanik, A. Zlobin, M. O. Diaz, P. C. Scacheri, and P. J. Harte. 2009. CBP-mediated acetylation of histone H3 lysine 27 antagonizes Drosophila Polycomb silencing. Development 136, 3131-3141.

25. Vakoc, C. R., M. M. Sachdeva, H. Wang, and G. A. Blobel. 2006. Profile of histone lysine methylation across transcribed mammalian chromatin. Mol. Cell Biol. 26, 9185-9195.

26. Wang, Z., C. Zang, J. A. Rosenfeld, D. E. Schones, A. Barski, S. Cuddapah, K. Cui, T. Y. Roh, W. Peng, M. Q. Zhang, and K. Zhao. 2008. Combinatorial patterns of histone acetylations and methylations in the human genome. Nat. Genet. 40, 897-903.

\section{초록 : 히스톤 H3K27 변형과 유전자 전사}

\section{김애리}

(부산대학교 자연과학대학 분자생물학과)

진핵세포의 크로마틴에서 히스톤 단백질 $\mathrm{H} 3$ 와 $\mathrm{H} 4$ 의 라이신 잔기는 공유결합에 의해 변형된다. 히스톤 $\mathrm{H} 3$ 에 서 27번 라이신은 아세틸화되거나(H3K27ac) 세 가지 단계로 메틸화가 될 수 있으며(H3K27me1, H3K27me2, $\mathrm{H} 3 \mathrm{~K} 27 \mathrm{me3})$, 이러한 H3K27의 변형들은 각각 독특한 형태로 유전자 전사 및 크로마틴 구조와 관련된다. 일반적으 로 H3K27ac과 H3K27me1은 좌위조절부위나 활발히 전사되는 유전자처럼 활성 크로마틴에서 나타나고, 이에 반 해 전사가 일어나지 않은 유전자는 높은 수준의 $\mathrm{H} 3 \mathrm{~K} 27 \mathrm{me}$ 과 $\mathrm{H} 3 \mathrm{~K} 27 \mathrm{me} 3$ 이 관찰된다. 이러한 변형들은 각각 다 른 종류의 변형효소에 의해 촉매된다. 최근 연구들은 유전자 전사 및 크로마틴 구조 형성에서 H3K27의 네 가지 변형들 사이에 상관 관계가 있음을 제시하고 있다. 